\title{
Empirical evolution of credit risk over a decade in IBEX 35 companies and its relationship with the qualification of its ratings
}

\author{
Josep Patau Brunet (iD \\ Escola Superior de Ciències Socials i de l'Empresa \\ TecnoCampus Mataró-Maresme, Universitat Pompeu Fabra (Spain) \\ jpatan@tecnocampus.cat
}

Received September, 2020

Accepted November, 2020

\begin{abstract}
Purpose: The present work responds to two objectives. On the one hand, it describes the evolution of the main economic-financial indicators that influence credit risk (insolvency) for a sample of 10 Spanish companies listed on the IBEX 35.This analysis is studied for a comparative period of 10 years, which coincides with a pre-crisis stage (2002-2005) and an economic post-crisis phase (2012-2015). On the other hand, it corroborates the relationship between the analysed insolvency and the rating or credit-risk rating published for these companies by an internationally recognized credit rating agency, Standard\& Poor's (S \& P).
\end{abstract}

Design/methodology: A sample of 10 companies and a 10-year period including the years 2002-2005 (pre-crisis) and the years 2012-2015 (post-crisis) are chosen, omitting the Spanish economic crisis that occurred in the year 2008. For the study of its evolution, 6 ratios obtained from the scientific literature that relate to credit risk and its effects on investments and company results are calculated. Finally, the correlations of these variables with the ratings of credit risk assessment by the rating agency $\mathrm{S} \& \mathrm{P}$ are measured. Descriptive statistics will assign value and graphics to this ten-year evolution, and with the incorporation of a factorial analysis, the correlation between the ratios and the S \& $\mathrm{P}$ rating will be determined. The statistical analysis explains this correlation to a greater extent.

Findings: The results show a clear increase in the value of the impairment variable due to credit risk ten years later that directly affects the results of the companies, despite these companies having significantly reduced their investments in commercial loans pending collection and drastically reduced the period means of collection of clients. In turn, there is a clear correlation between the insolvency studied and the variables used by the $\mathrm{S} \& \mathrm{P}$ rating agency for the assessment of credit risk.

Originality/value: The empirical study concludes that there is a correspondence between insolvency and the rating given by an internationally prestigious rating agency $(\mathrm{S} \& \mathrm{P})$ for the sample of 10 companies studied. Three variables - customer balance-accounts receivable, investments and the net amount of turnover - are determining factors explaining this correlation, and these three variables are the same ones that decisively influence both the pre-crisis period and the post-crisis period 10 years apart. The rating agencies weigh the insolvency variable in their analyses.

Keywords: Credit risk, Insolvency, Credit evaluation (rating) 
Jel Codes: M41 Accounting

\section{To cite this article:}

Patau Brunet, J. (2020). Empirical evolution of credit risk over a decade in IBEX 35 companies and its relationship with the qualification of its ratings. Intangible Capital, 16(2), 61-77.

https://doi.org/10.3926/ic.1961

\section{Introduction}

When a company is incorporated into the business world and assumes the rules of the markets, it is fully aware that this procedure entails assuming a series of risks. One such risk is the risk of default that may result from the commercial relationships maintained with other entities, which we will call client-debtors. We define this risk, called credit risk, as the possible loss assumed by an economic agent as a consequence of a breach of contractual obligations incumbent on counterparts with which it relates. Such a risk is not subject to control by the agent, although the agent has the option to insure it through duly specialized companies by means of the assumption of some costs; for example, the economic operations protected by an insurance guarantee amount to 137,000 million euros, almost 14\% of the Spanish GDP (Unespa-Insurance Business Association, 2009).

Credit risk is inherent to a company, and zero risk does not exist. Therefore, companies must learn to live with credit risk and manage the delinquency of their clients-debtors in the best possible way so that their incidence is the least burdensome to our interests.

Late payment has been, is and will be a drag on the business fabric. Mariano Reyes writes (quoted in Brachfield, 2006) that the high death rate of Spanish SMEs is due in large part to late payment and that one of every three bankruptcies in Spain is caused by delays in bill payments. He adds that what is worrying is that most of the defaults that occur in Europe are intentional and that the percentage of these defaults in Spain $(5.1 \%)$ is double that of the rest of the continent $(2.6 \%)$.

It seems that delinquency has become normal and commonly accepted. This variable, which is difficult to control and monitor, can have disastrous consequences for the good progress of creditor companies that have been surprised by the entry into bankruptcy of any of their debtors. Delinquency considerably limits the regular financing of assets and results in important changes in terms of profitability, liquidity and degree of indebtedness.

Instituto Nacional de Estadística (2007) established that, in the most recent pre-crisis years, $50.79 \%$ of the companies that are born in Spain do not live long enough to celebrate their fifth anniversary; the lack of business training and the delay in collecting bills are two of the threats; and this figure increases to $56.54 \%$ in the postcrisis period 2010-2014 (Instituto Nacional de Estadística, 2017).

According to data from the Multisectorial Platform for Combating Late Payments (Plataforma Multisectorial De Lucha Contra La Morosidad, 2010), this problem is the leading cause of insolvency in Spain in 67\% of business closures that have occurred since 2007. The main reason was the delay in the collection of invoices, which has left creditors without liquidity and with treasury problems.

A company becomes insolvent when it cannot meet the payment of its debts on the corresponding due dates. According to Suárez (2003), this result occurs due to poor treasury management when assets (total investments) exceed liabilities (total of other debts). In these cases, when the cessation in the payment of obligations is temporary or transitory, the insolvency is called technical insolvency, suspension of payments or transitory insolvency. On the other hand, when, in addition to the cessation of payment, the value of assets is less than that of liabilities (that is, when equity is negative), the company faces a state of economic insolvency, bankruptcy or final insolvency. 
Associated with the suspension of payments and bankruptcy are separate legal proceedings that lead to the legal declaration of each state to protect the legitimate interests of the creditors. Bankruptcy can mean the death or disappearance of the company. The suspension of payments, on the other hand, tries precisely to avoid the definitive disappearance of the company by facilitating the establishment of an agreement between it and its creditors. Through this approach, the company is granted a deferment, moratorium or withdrawal for the payment of its debts. As a result of the appearance on the scene of the new law 22/2003 of July 9, Bankruptcy, the judicial procedure was unified and came to be called bankruptcy. Thus, entities subject to this process were designated insolvent debtors. The bankruptcy law owes its name to the concurrence of creditors on common debtor's assets.

See Table 1, which shows, by way of example, the evolution of the number of companies that request bankruptcy during the decades studied. No data appear in the years 2002 and 2003 because the bankruptcy law (22/2003 of July 9) appeared in mid-2003, and with it, there was the creation of the mercantile courts to decide these issues. It is not until fiscal year 2004 that there is real and concentrated information about the bankruptcy situations presented and, in this case, only for the last four-month period. The table shows the evolution bankruptcy has had: compared to 2005 (1,001 companies), the number of companies submitted to the process ten years later had increased by a factor of 5.7 (5,746 companies) and was even multiplied by almost 10 two years previously in 2013 (9,937 companies).

\begin{tabular}{|c|c|c|c|c|c|c|c|}
\hline 2002 & 2003 & 2004 & 2005 & 2012 & 2013 & 2014 & 2015 \\
\hline $\begin{array}{l}\text { ND } \\
\text { NA: }\end{array}$ & $\underset{\text { ankruptey }}{\text { ND }}$ & $\underbrace{200 \text { (1) }^{\text {(1) }}}_{\text {2003 of } \mathrm{jul}}$ & $\begin{array}{c}1.001 \\
\text { Last quar }\end{array}$ & 9.071 & 9.937 & 7.280 & 5.746 \\
\hline
\end{tabular}

Table 1. Evolution of the number of companies that apply for bankruptcy Creditors in Spain during the years studied (INE, 2017)

The identification of valid indicators to predict corporate insolvency has been a constant in the investigation of the accounting and financial area in recent decades. The lack of a positive theory on this issue has forced researchers to approach it from a purely empirical perspective. With the emergence of different predictive models, the new avenue of open accounting research has incorporated abundant accounting discipline literature, in which the financial information of companies has acquired greater prominence and one of the variables used is credit risk.

The most relevant works on the investigation of business failures, where credit risk acquires greater severity, correspond to two authors: Beaver (1966), who conducted an analysis of business crises by applying accounting ratios univariately, and Altman (1968), who also used multidiscriminant analysis to predict corporate bankruptcy based on accounting ratios. Note the difficulty in those times of handling a large amount of information without having the computer resources that exist today. Therefore, it is not risky to say that the decade of the sixties marked the beginning of this line of research.

In turn, in terms of credit risk, we highlight the changes that the banking sector has made with the New Basel II Agreement. Its foundation is that capital requirements are more sensitive to risk, especially credit risk. The current agreement is focussed on a single risk measure, a single suit system and a simple structure. The proposal of the new Agreement places more emphasis on the internal credit risk measurement models of each bank, the supervisor's review and the market discipline; it is more flexible, it has several approaches and incentives, but it is also more complex. Although the banking sector will not be part of the object of this work, it is good to take it into consideration due to the substantial advantage that this sector has with respect to the rest of the business sectors in terms of the sensitivity generated to control and manage the risks of credit.

Finally, we highlight that credit risk is one of the variables used by credit rating agencies or ratings. The main objective of these institutions, which are associated with the financial system, is the valuation and quantification 
of the credit risk associated with the public and private debt issues that are traded in the capital markets. Through this valuation, they issue a rating or ratings to give an opinion on the instrument issued and the economic-financial health of the issuer to meet the obligations contracted with its investors. These institutions are accused in some cases of a lack of transparency, of provoking speculations in the financial markets and of acting according to who pays them; refer to the bankruptcy of the energy corporation Enron (2001) or the bankruptcy of Lehman Brothers (2008), among others.

The rating agency market has been concentrated in three large and historic organizations for years: Standard \& Poor's, Moody's and Fitch Ratings. The "Big Three", as they are known in the Anglophone world, have benefited from years of special distinctions granted by regulatory institutions, such as the American NRSRO (Nationally Recognized Statistical Rating Organizations). In our case, we will focus on Standard \& Poor's (S \& P), which appears as a result of the merger of Poor's Publishing and Standard Statistics in 1941, although its roots go back to 1860 .

\section{Literature review}

There is an extensive literature about credit risk in the business sector. In our case, we wanted to limit our analysis to the concept of commercial credit and the specific variables to study and evaluate this credit risk over time, which will help us to carry out our empirical analysis and determine whether there is a relationship with the credit ratings offered by the rating companies.

Reierson (1959) referred to the risk of default seen from a customer's point of view. It was suggested that the demands for short-term commercial credit would increase rapidly and significantly, concentrating its strength on less durable products. This demand would expand into commercial relationships, where the risk of default would be higher and would affect the results of the company and its liquidity. However, this credit policy would cause an increase in turnover.

Commercial credit allows companies with difficulties in accessing institutional financing to obtain funds through a commercial relationship that is established with companies that can present, a priori, a greater facility to obtain credit in the financial markets. This aspect is indicated in Schwarts (1974) and Emery (1984); however, this excess of investment in cash must be considered by the selling company to see how it affects that company's liquidity.

In turn, Cea (1992) understands credit risk as the set of factors or circumstances that determine or affect the achievement of the result at present and in the future, so that business risk is defined as the risk of obtaining of income, which directly affects the potential delinquency of our client-debtor and the economic-financial consequences that may occur in our financial statements, both at the patrimonial level and at the level of results.

Other authors, among whom we highlight Chuliá (1991, 1992 and 1993), García Vaquero and Maza (1996) and Hernández de Cos and Hernando (1999), carry out studies in which the existence of a size effect was found, pointing out that smaller companies are those that most often resort to financing via suppliers. In such cases, the risk of not being paid and its consequences may be greater, which results in less liquidity, greater investment in cash, longer payment terms and an impact on results. García Pérez de Lema, Calvo-Flores Segura and Arqués Pérez (2000) also associate the size effect with the concept of financial risk and argue that smaller companies have greater exposure to risk by having a less favourable debt structure and lower economic profitability.

According to Garrido (2000), the approach of a credit policy to customers involves analysing the real possibilities of financing the sales or turnover that the company wants to achieve, quantifying the cost of financing sales and, of course, assuming the risk of possible losses due to final insolvencies of one or more of the clients. Therefore, Vidal (2001) incorporates a new element of analysis, accounting, which should be an indispensable tool for adequate and rational financial decision-making and could be expected to provide third parties useful information to assess profitability and the risk of the company. However, the references that may be useful in the assessment of risk are insufficient, and the limited information provided on risk is dispersed in the information provided by the companies without any type of systematic management or treatment. 
Similarly, the Commission of Experts of the White Book for the reform of accounting in Spain, and itspresident, Gonzalo, J. (2002), understand that this commission should boost the information on enterprise risks until other less radical formulas such as the allocation of a point in the annual accounts

At a meeting held in October 2002, the International Accounting Standars Board-IASB (2005) identified the need to develop a document that contains information beyond the annual accounts, reflected in the project management commentary (MC), where investors become the main users, since such a document would allow investors to better understand financial statements. The point of departure was to find a relationship between financial information (developed through traditional financial statements) and the importance of other information that should accompany these statements to complete them; among that other information were potential credit risks.

The lack of published information on credit risk in the financial statements does little to solve this climate of distrust on the part of investors. This lack is irremediably linked to the fact that, in the vast majority of business crisis scenarios, the audit reports have no reserves that would alert partners, creditors or the market in general (Fernández del Pozo, 2001). This point leads us to affirm that the mechanisms established by the order for the detection of crisis situations, as well as the public information available to all interested parties, are neither sufficient nor, above all, efficient (Vicent Chuliá, 2002) because they do not allow knowing pre-insolvency situations if the administration body does not communicate them.

The contribution of Jiménez and Saurina (2006) is to offer evidence of a positive relationship, although outdated, between the rapid growth of credit and future delinquency ratios. Moreover, they find a direct relationship between the phase of the credit cycle in which the operations are granted and the standards of the credit policy at that moment. Thus, credit risk increases in periods of economic expansion, but it only shows up as credit losses during recessions, which will greatly depend on the moment and economic environment in which we are moving.

Thus, for Argüelles (2007), interest in the information provided by companies to external users is increasingly growing, since the environment in which business is conducted is more international and more globalized. Thus, agents are increasingly interested in receiving financial statements prepared by companies as a true reflection of the situation they are going through and the results they obtain. He adds that the needs of users go further, not only being limited to financial statements but also requiring nonfinancial information. In this nonfinancial information, there is room for all the movement derived from the different risks that occur to the company, especially the commercial credit risk.

This need for additional information that the financial statements do not provide is where risk rating agencies take centre stage, where through econometric models in which they use different variables they try to assess the economic potential of the analysed subject. According to Agnew (2012), their notes or ratings assess the risk of default and the deterioration of the solvency of the issuer. These institutions, being private, have an independent assessment structure, so the qualification depends on the detailed study carried out, given that their opinions will fully affect decisions that may be made by third parties external to the company.

Triple and Idea (2009) argue that among valuation methods, these rating companies focus their studies on two basic concepts, liquidity and solvency, as they are considered indispensable factors for the stability of a company concerning meeting its short- and long-term obligations. However, despite being strongly linked factors, they do not necessarily have to be reciprocal. A company may count on a high level of liquidity that is nonetheless insufficient to deal with the liabilities of the company; alternatively, the company may have solid solvency, but its liquidity may prevent it from facing short-term debts.

However, discordant comments appear. For example, Eijffinger (2012) assesses the role of credit rating agencies during the sovereign debt crisis in the European Union in the 2010-2011 period. The study concludes that the 3 major agencies, including Standard \& Poor's, have a too strong market position due to lack of competition. The study also argues that the dependence on credit rating agencies should be reduced to less importance and that they should provide greater transparency to increase the quality and reliability of their ratings. Dominique Shaw 
Kahn, former director of the International Monetary Fund, said in April 2010, "rating agencies do not always succeed. People believe them and that is why they have influence in the short term, but in the long term what predominates are other factors. "

However, to cite an example, in the face of constant manifestations showing that rating agencies may conspire to assign inflated ratings due to the incentives they may have from the companies analysed, Stolper (2009) shows that there is a scheme of approval that induces the credit rating agencies to assign correct ratings, thus counteracting some of the discredits attributable to the agencies themselves.

According to Regulation 1060/2009 of the European Parliament and the Council, dated September 16, 2009, regarding credit rating agencies, a European supervisory body called the European Securities Market Authority is created with the objective of supervising the activity of credit rating agencies. This supervision is supported at the national level by the National Securities Market Commission, which focuses on efficient European supervision via collaboration between the different national supervisory bodies and the European central body. However, it is essential to highlight that the rating agencies are registered as journalism agencies; thus legally, their only job is to provide information. For example, they are not subject to the rules of rights, duties and responsibilities of the audit firms that should preserve the transparency of their reports.

Examining more deeply the relationship between credit rating and credit risk, Abad and Robles (2014) analyse the relationship between the announcements of changes in the rating assigned to corporate debt and the risk levels of the issuing company. This study also analyses changes in the companies that quote or have been quoted in the continuous market between 1988 and 2010 when the debt ratings of Spanish companies have been announced by the 3 main rating agencies, among them, again, Standard \& Poor's. The results show changes in risk level directions signalled by the change in rating.

Hilscher and Wilson (2017) argue that if the ratings should be informative indicators of credit risk, they should reflect what matters to an investor who is risk averse; therefore, they investigate the probability of default of their obligations as the risk associated with it. They detect that a model is used to predict failure based on publicly available financial information; thus, a quantity of information relevant to the investor who must make decisions is lost. Therefore, they conclude that it is not possible for one measure to capture all relevant data for decision making, although rating information gives us a first impression about the good economic-financial health of companies.

To respond to this lack of information, Samaniego, Trujillo and Martín (2006) had at the time already joined to investigate the evolution of credit risk, producing a comparative analysis of accounting models and market models applied to the Spanish stock market along the same lines as the database that occupies us in this work. The authors conclude that there is a certain degree of positive linear association between the credit ratings provided by the accounting model through its financial statements and those based on market data, which allows such models to provide similar results in most sectors analysed, except for the technology sector and the real estate sector, as both are very volatile sectors at the current juncture. In this work, we use accounting ratios for the evaluation of credit risk.

\section{Design and methodology}

\subsection{Sample}

The sample consists of just 10 companies (see Table 2) that are quoted on the IBEX 35 reference stock exchange index of the Spanish stock market prepared by Bolsas y Mercados Españoles (BME); the IBEX 35 comprise the 35 most liquid companies listed on the Spanish Stock Exchange Interconnection System (SIBE) on the four Spanish stock exchanges (Madrid, Barcelona, Bilbao and Valencia). There are only 10 companies for two reasons: a) those companies in the banking sector quoted on the IBEX 35 are omitted from the analysis because they depart from the initial objective of commercial credit risk analysis, since they have different performance characteristics than do industrial and commercial companies, and b) only these 10 companies repeat their quotationson the Spanish stock market ten years later and all have a credit rating by the Standard\& Poor's 
appraisal company. A ten-year period is chosen from the years 2002-2005 (pre-crisis) to 2012-2015 (post-crisis), specifying the beginning of the Spanish economic crisis in 2008 according to the National Institute of Statistics (2017).

\begin{tabular}{|c|c|c|c|c|c|c|c|c|c|}
\hline 1 & ACS & 3 & ENDESA & 5 & IBERDROLA & 7 & MAPFRE & 9 & REPSOL YPF \\
\hline 2 & ENAGAS & 4 & FERROVIAL & 6 & INMOBILIARIA COLONIAL & 8 & RHD E-ECTRCA ESPAÑOLA & 10 & TEEFONICA \\
\hline
\end{tabular}

Table 2. IBEX 35 companies that are part of the sample under study

\subsection{Variables}

The variables chosen to analyse the credit risk are obtained from the consolidated annual accounts that the companies publish in the mercantile registers impairment due to credit risk, the balance of accounts receivable, the average collection period, the investment in current assets and total investments. In turn, we add the turnover and the results obtained after tax. All variables are obtained from the scientific literature.

Standard \& Poor's rating company obtain the credit evaluation ratings of the 10 IBEX 35 companies during the periods studied. Following the educational tradition in English-speaking countries, grades are assigned by letter, in alphabetical order from best to worst. Thus (see Table 3), an "AAA" rating denotes a high-quality payment capacity, a "BBB" rating denotes speculative investment with medium- and long-term risks, and a "C" or "D" ratings indicate a current or imminent bankruptcy situation. In addition, each agency keeps the possibility of applying "+" or "-" badges as a subcategorization. The ratings are usually accompanied by a perspective on the future of the agency (where the rating could vary in a short term): neutral (most common), positive or negative.

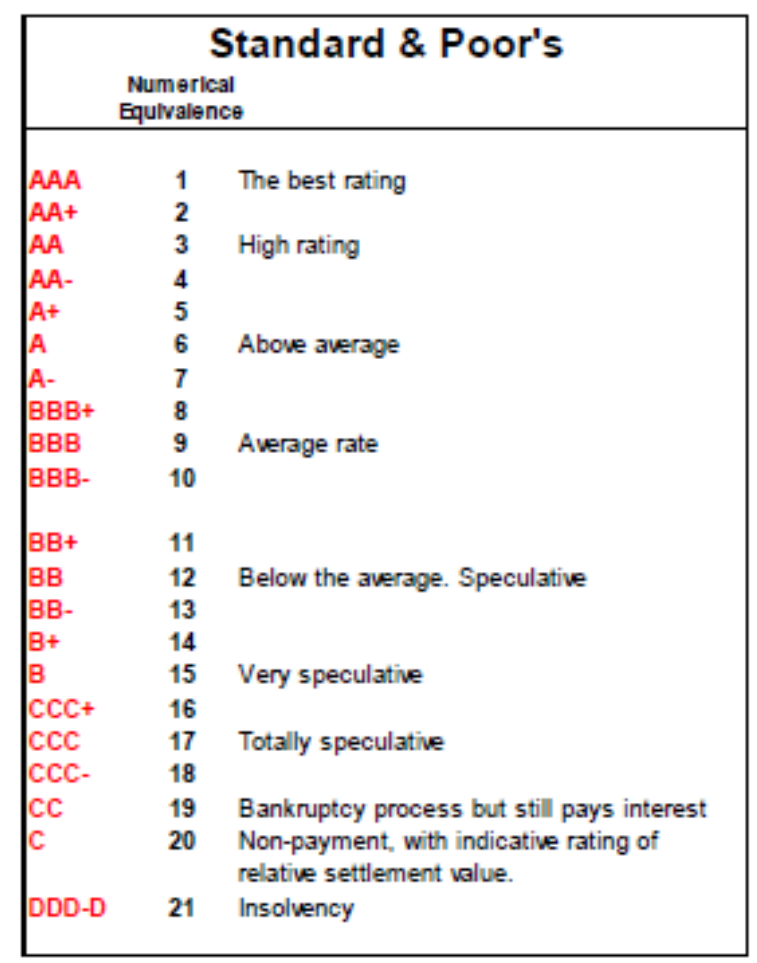

Table 3. Credit rating of the company Standard \& Poor's with its numerical equivalence for statistical purposes

Although none of the ratings are binding (that is, they are the result of variable and controversial observations), they do theoretically have a direct impact on the price that a company is indebted for. The higher the risk is, the more attractive the return (the interest and benefits outlined) will be to attract investors, and vice-versa: if a 
company improves its rating, it will be able to issue bonds with a lower interest rate, given that the probabilities of default decrease (and confidence in the investment increases). Given that the ratings are alphabetic, we assign (see Table 3) a numerical equivalence for statistical purposes that provides us with greater ease of calculation, so that the lower the assigned number, the higher is the qualification obtained, a value of 1 being the best possible rating.

\subsection{Methodology}

The use of traditional financial statements (balance sheet and income statement) becomes an essential requirement for our objective. Nonetheless, no less important will be the use of tools to homogenize all this information, such as the economic-financial ratios and the statistical techniques used for this purpose.

The ratios have been consolidated as a tool used by experts to perform an analysis of financial statements. The use of these ratios, both in the study of their evolution over time and in comparisons with other entities, has become widely disseminated thanks to their advantages as an element of the relationship between all types of indicators.

In any case, the review of the literature does not give a clear idea about what the categories of essential ratios should be. Therefore, there is no theory that guides the researcher on which variables to use for this type of research (Lev, 1978; Zavgren, 1983; Jones, 1987). Absent such a theory, the tendency is to use those that enjoy greater popularity in the scientific literature.

In the first research work on ratios, prominent authors insisted on the advantages that these instruments can have on other financial measures. Among the arguments that have been given in favour of financial ratios, Whittington (1980) emphasizes that this approach is the best to eliminate the influence of the size of the companies under analysis. This advantage means that the quotient between items in the financial statements allows comparisons of companies of different sizes to be made.

Several authors have provided reasons in favour of examining the financial data in ratio format and of univariate analysis, among whom Foster (1986) defends that this technique a) controls the size differences between companies, b) facilitates, over time, the formulation of statistical analysis inference tables, c) allows research through a theory in which the ratio is a relevant variable and d) allows us to take advantage of the analysis of the empirical regularities observed between the financial ratios and the estimation or prediction of the variables of interest.

The ratios chosen for the statistical analysis are described in Table 4.

\begin{tabular}{|c|c|c|c|c|c|c|}
\hline R1 & $=$ & (Provision for traffic insolvencies & / & Balance customers and accounts receivable) & $\mathrm{x}$ & $100=$ \\
\hline R2 & $=$ & (Balance customers and accotunts receivable & / & Current Assets) & $\mathrm{x}$ & $100=$ \\
\hline R3 & $=$ & (Balance customers and accounts receivable & / & Total Assets) & $\mathrm{x}$ & $100=$ \\
\hline R4 & $=$ & (Balance customers and accounts receivable & / & Net amount of tumover) & $\mathrm{x}$ & $365=$ \\
\hline R5 & $=$ & (Provision for traffic insolvencies & / & Result of the exercise after taxes) & $\mathrm{x}$ & $100=$ \\
\hline R6 & $=$ & (Result of the exercise after taxes & 1 & Net amotunt of tumover) & $x$ & $100=$ \\
\hline
\end{tabular}

Table 4. Description of the ratios used for the analysis of Credit Risk

With the results obtained from the ratios, the arithmetic mean is calculated for each of the years studied for the 10 companies in the sample. Also calculated are the averages of the two pre-crisis and post-crisis periods to analyse, through graphs, the evolution and change provided by a decade of difference. Further, we will try to observe the correlation that exists between a variable called insolvency created through the different variables 
that make up the ratios and the rating of the ratings provided by specialized and renowned companies operating at an international level, such as Standard \& Poor's, through a factorial analysis, thus highlighting those variables that strongly influence the variability of the data.

\section{Implications and results}

In this section, we analyse the evolution of the different ratios by means of graphs, where the statistical mean is incorporated for each of the years studied in addition to the statistical average for the four years as a whole, differentiating a pre-crisis period and a post-crisis period with the intention of analysing the evolution of data with 10 years of difference.

Figure 1 shows the evolution of the average of the R1 ratio. The risk of default provided as a provision for traffic insolvencies has increased by $54 \%$ of the average of the post-crisis period (10.0) with respect to the average of the pre-crisis period (6.5) ten years later. The delinquency after the crisis has been accentuated, which will affect the results of the companies in the sample, as this provision is an item of expenditure.

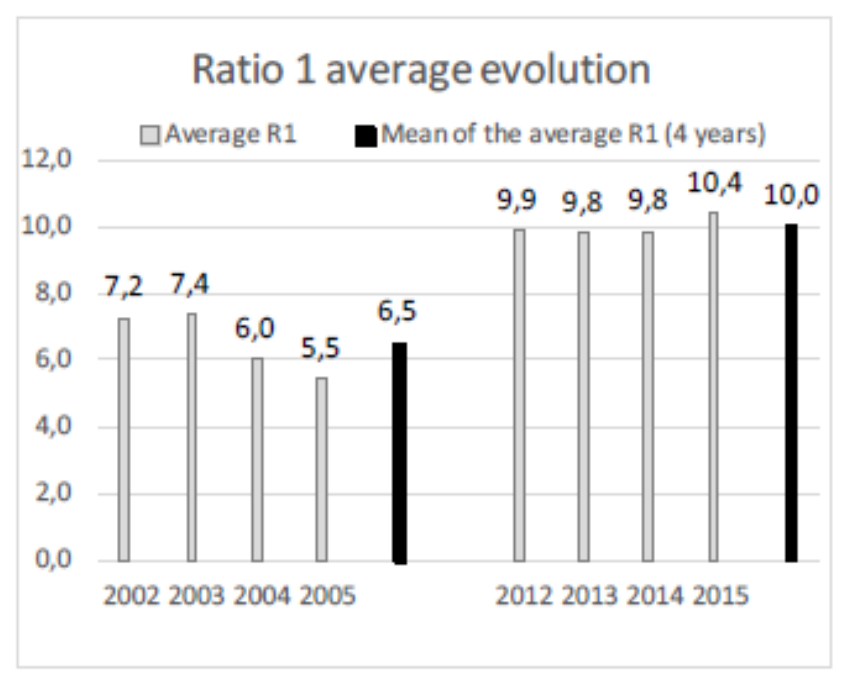

Figure 1. Evolution of the statistical mean of the R1 ratio

However, Figure 2 indicates that the proportion of the commercial credit investment of the post-crisis period (21.6) with respect to the proportion to the pre-crisis period (31.5) has decreased by $31 \%$ with respect to the investment in current assets a decade later; even so and as we have seen in the R1 ratio, the provision for insolvencies has increased.

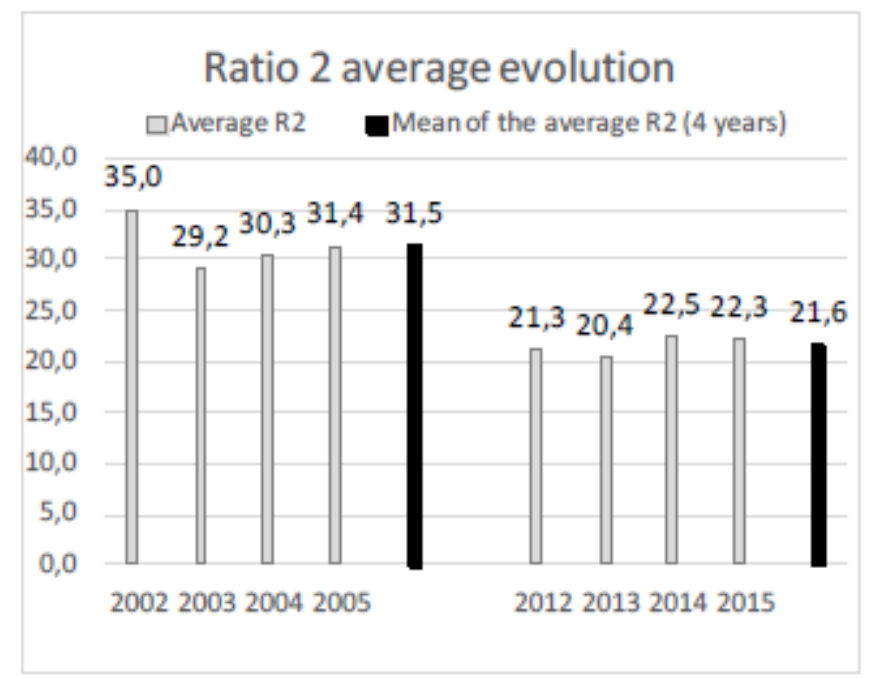

Figure 2. Evolution of the statistical average of the R2 ratio 
Similarly, in Figure 3 and consistent with what we noted in Figure 2, the proportion of the investment of the post-crisis period (5.4) with respect to the proportion of the pre-crisis period (8.9) has decreased by $39 \%$ when we compare the investment of the balance of accounts receivable with respect to the total investments of its assets.

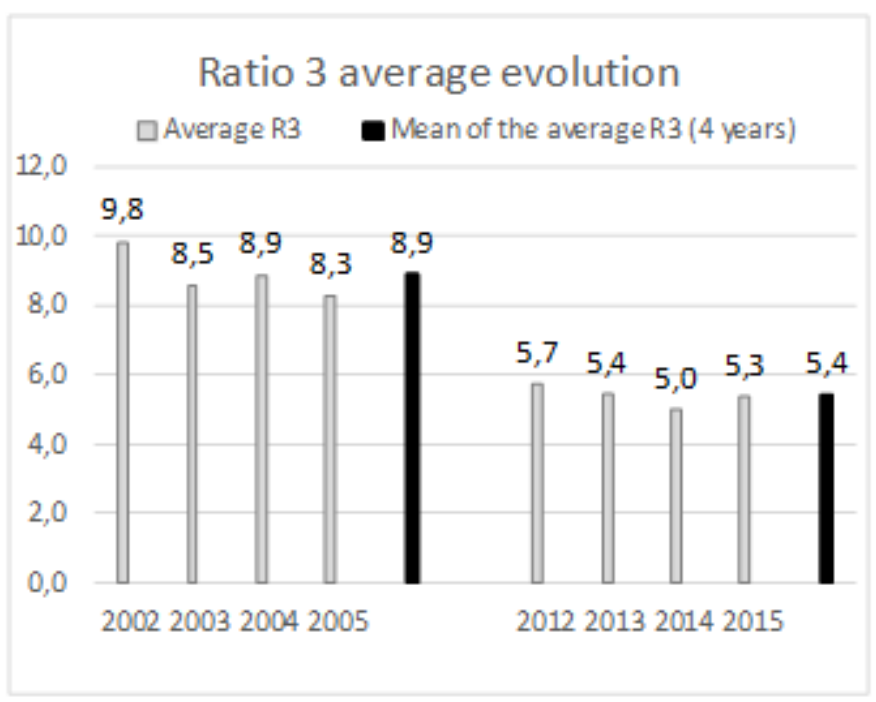

Figure 3. Evolution of the statistical mean of the R3 ratio

The reason that these two previously determined means decreases is explained in Figure 4, where the average collection period has been considerably reduced; this one in the pre-crisis period was 73.2 days. However, ten years later, the companies reacted and managed to lower the average payment term by approximately 30 days to 43.0 days, which means a $41 \%$ decrease in investments required to maintain commercial credit in days pending collection.

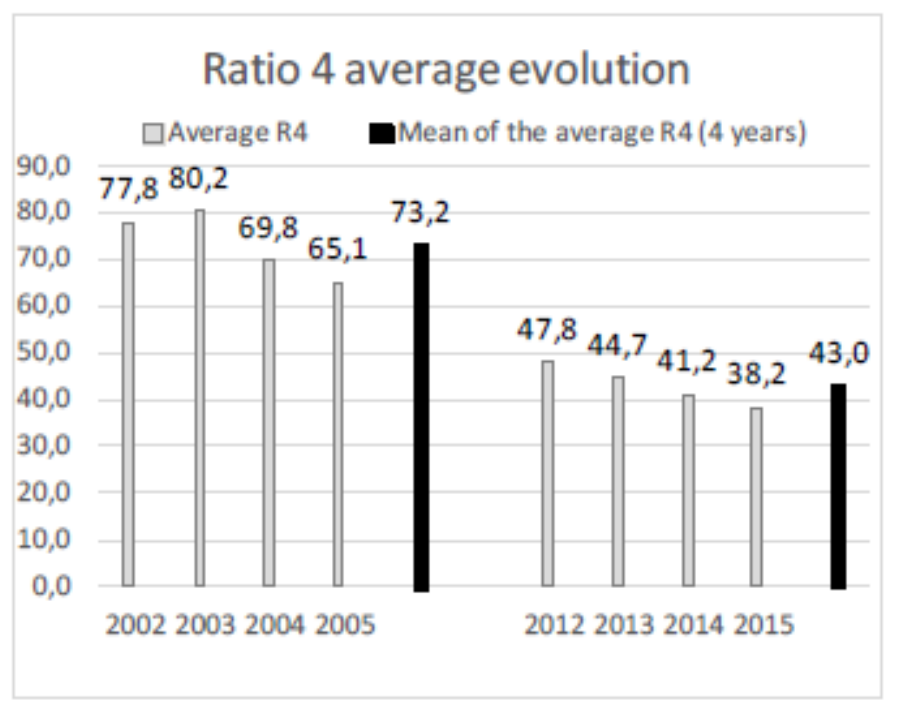

Figure 4. Evolution of the statistical mean of the R4 ratio

Figure 5 explains the impact of the provision for traffic insolvencies with respect to the result of the fiscal year after taxes; the proportion of credit risk, which has increased by $54 \%$ in Figure 1 and where we were already making progress that would affect the company's results, increases its effect on the result of the year after taxes by $107 \%$, showing a value of 24.9 in the post-crisis period with respect to a value of 12.0 in the pre-crisis period. As a result, the impact of the provision for insolvencies doubled its negative effect on the income statement 10 
years later, despite having reduced the average collection period, and significantly reduced its investment in commercial credit. The companies in the sample have not been able to stop the constant increase in the insolvency of their customers and have been forced to double their provisions for commercial deterioration.

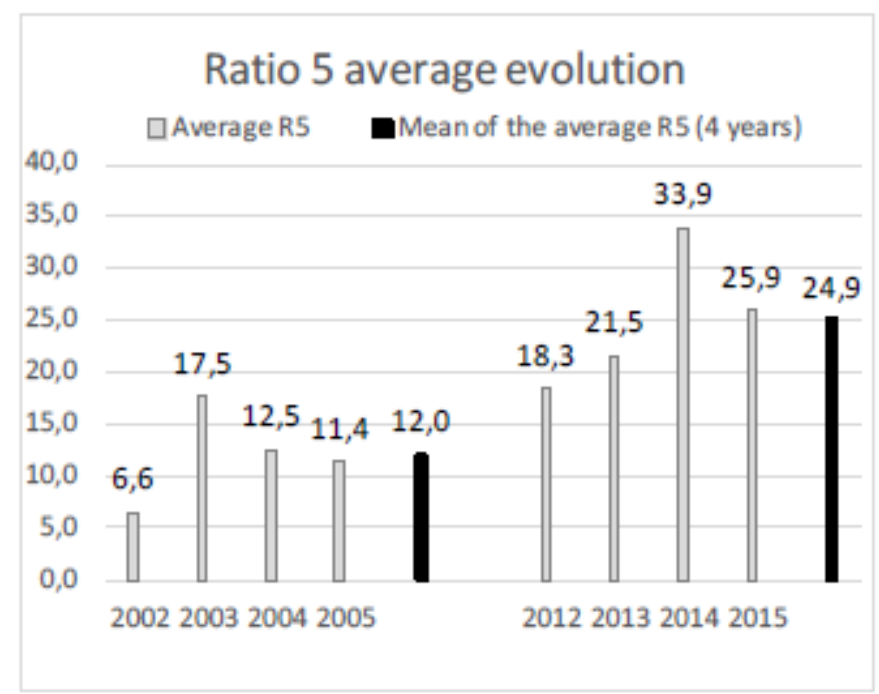

Figure 5. Evolution of the statistical mean of the R 5 ratio

Figure 6 shows the economic profitability of the result of the fiscal year after taxes with respect to the net amount of the turnover. Ten years later, there is a change of sign in the results of the companies in the sample, going from positive average returns (18.3) in the pre-crisis period to negative average returns $(-5.0)$ in the postcrisis period. However, we cannot determine with rigor the proportion or impact that these provisions have for traffic insolvencies in this change of sign because there are many factors linked to the economic-financial crisis that affect the results of the companies in the sample to a greater or lesser extent.

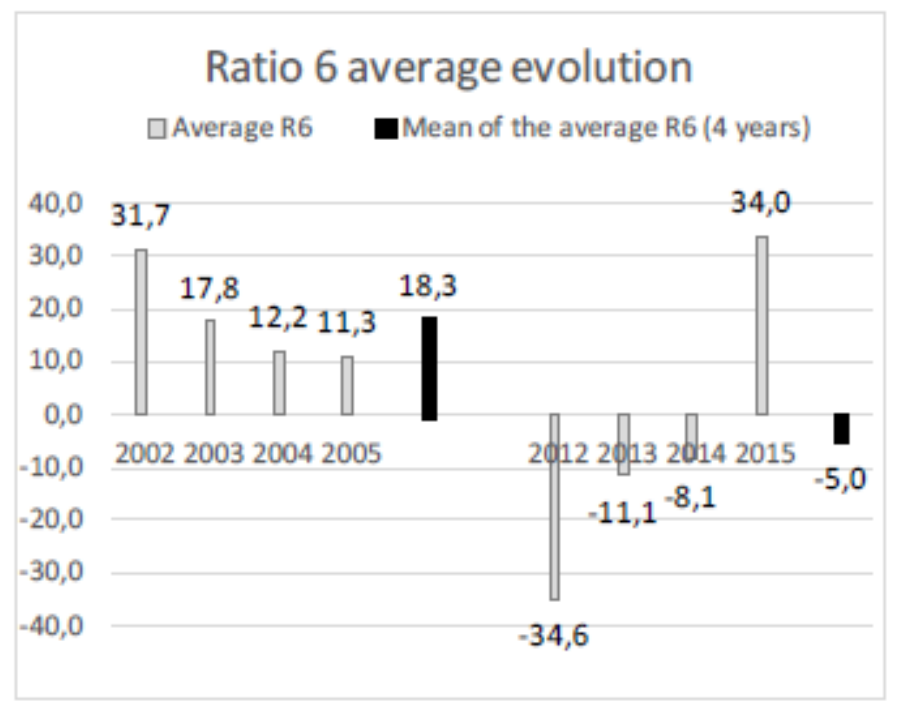

Figure 6. Evolution of the statistical average of the R6 ratio

Finally, Figure 7 provides information on the evolution of the average rating of Standard\& Poor's. In Table 3, we have shown the numerical equivalences of the ratings, which follow an alphabetical classification that is not standardized. However, if it is parameterized, then when there are different rating companies, each one emits its own evaluation; thus, we focus on $\mathrm{S} \& \mathrm{P}$. The average of the companies in the sample showed, for the pre-crisis period (2002-2005), a rating between A and A-, a value above average according to the S \& $\mathrm{P}$ company itself. Ten 
years later and in an economic post-crisis period (2012-2015), the average of the valuations of the 10 companies in the sample has decreased to a valuation between BBB and BBB-, which is considered an average valuation, with a consequent worsening of the credit evolution (we remember that the greater the number assigned, the worse the valuation was).

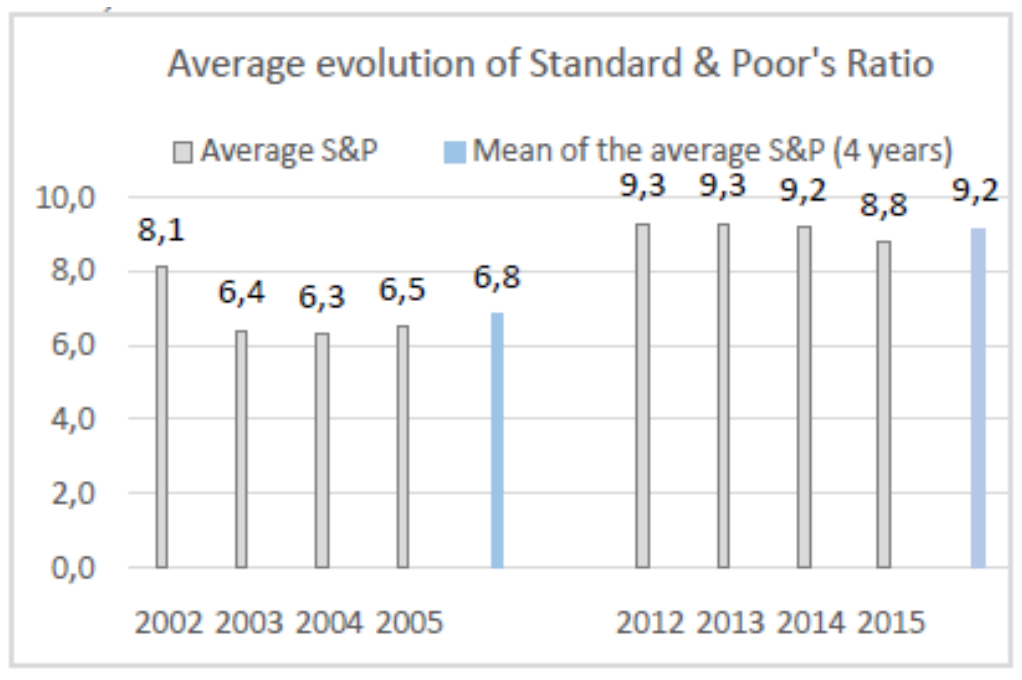

Figure 7. Evolution of the statistical average of the Standard \& Poor's ratio

Companies lose their qualifications after the economic crisis, and one of the variables used for rating companies is the risk of insolvency and the possibility of realizing their receivables. To determine whether there is any type of correlation between the provision for business insolvencies, their investments within their assets and their effect on the income statement with respect to the S \& P rating of their credit rating, we perform a factorial analysis developed in two different stages: pre-crisis (2002-2005) and post-crisis (2012-2015).

For the pre-crisis period, Figure 8 explains the model we use to observe this correlation; from the study of the six pre-crisis ratios, where insolvency is analysed from different perspectives and over a period of 4 years, a synthetic variable will be obtained that we call "Insolvency", created from the variables resulting from the factorial analysis and via regression of factors. We calculate the correlation index with the $\mathrm{S} \& \mathrm{P}$ rating, where we obtain a result of $32.9 \%$ with a level of significance of $95 \%$.

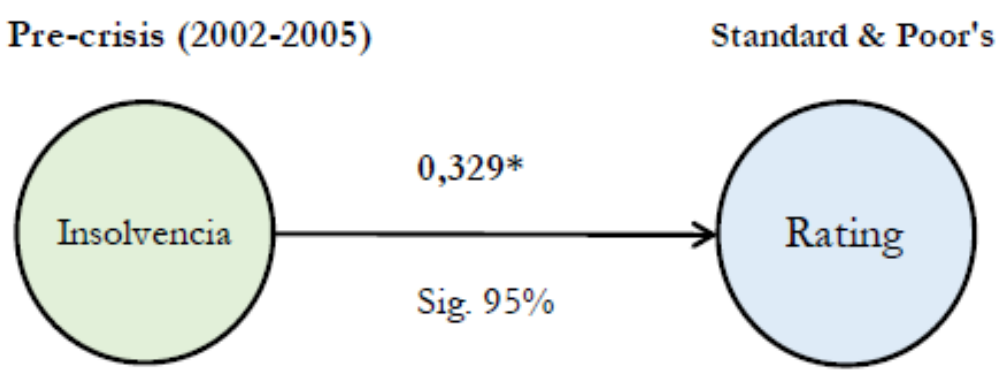

Figure 8. Model and results of the analysis of the pre-crisis period (2002 to 2005)

For the above, we have used a factorial analysis to ascertain the components that best explain the insolvency variable. Three ratios have influence and show high correlations with the index "Insolvency", R2 (0.927), R3 (0.873) and R4 (0.748) (Table 5), following the values established in Loiacono, Watson and Goudhue (2002), which require a minimum value of 0.5 . 
In turn, the value of Cronbach's alpha is calculated. This coefficient serves to measure the reliability of a measurement scale through a weighted average of the correlations of the variables and is usually used as an index of internal solidity. Authors such as Carmines and Zeller (1979) establish that for an analysis of nonstandardized Cronbach's alpha, the observed value should be approximately 0.7 ; in our case, the result obtained is 0.778 .

As a final point, the measure of variability that gives us information on the degree of homogeneity of the observed group is $72.70 \%$.

\begin{tabular}{|lccc|}
\hline Explanatory variables & R2 & R3 & R4 \\
Factorial Analysis & 0,927 & 0,873 & 0,748 \\
Loir cono et al (2002) valor min. 0,5 & & & \\
Cronbach Alpha & 0,778 & \\
Camines y Z eller (1 979) valor min. 0,7 & & & \\
Explained Variance & & $72,70 \%$ & \\
\hline
\end{tabular}

Table 5. Statistical results of the factor analysis for the pre-crisis period (2002 to 2005)

Similar analysis was performed on data for the post-crisis period (Figure 9), where a result of $38.2 \%$ is obtained to determine the correlation index of the artificial variable called "Insolvency" with respect to the rating of the company S\&P, with a level of significance of $95 \%$.

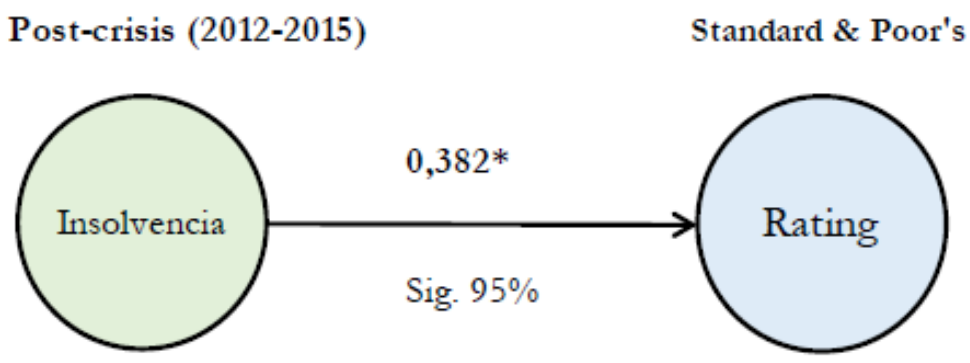

Figure 9. Model and results of the analysis of the post-crisis period (2012 to 2015)

In this post-crisis period, it is determined that the same ratios that had an explanatory influence on the variable "Insolvency" in the pre-crisis period, and R2, R3 and R4 are the same variables that influence this period: R2 (0.825), R3 (0.887) and R4 (0.790) (Table 6). These variables produce a value of $72.70 \%$ for Cronbach's alpha, which is again within the margins established by Carmines and Zeller (1979) for delving into the reliability of the results, and an explained variance of $69.74 \%$ was obtained.

\begin{tabular}{|lccc|}
\hline Explanatory variables & R2 & R3 & R4 \\
Factorial Analysis & 0,825 & 0,887 & 0,79 \\
Loiacono et al (2002) valor min. 0,5 & & & \\
Cronbach Alpha & & 0,721 & \\
Camines y Zeller (1979) valor min. 0,7 & & & \\
Explained Variance & & $69,74 \%$ & \\
\hline
\end{tabular}

Table 6. Statistical results of factor analysis for the post-crisis period (2012 to 2015) 


\section{Limitations}

The financial companies are eliminated from the sample of the IBEX 35 because they have different characteristics regarding credit risk with respect to the rest of the companies.

Concerning the size of the sample, when studying a 10-year period, only 14 nonfinancial companies of the IBEX 35 repeat a quotation a decade later, which greatly limits the chosen sample. In addition, of these 14 companies, only 10 have a credit rating by the rating agency Standard \& Poor's; thus, we are forced to eliminate 4 companies from the initial sample.

\section{Added value and conclusions}

This section responds to the first objective raised regarding the evolution of the main economic-financial indicators that influence credit risk (insolvency) for a sample of 10 Spanish companies listed on the IBEX 35. The samples were studied for a comparative period of 10 years, and based on the post-economic crisis (20122015) and with respect to the pre-crisis stage (2002-2005),we concluded the following:

(a) The R1 ratio shows that there has been a significant increase in credit risk, by $54 \%$ on average, between the values shown in the post-crisis period with respect to the pre-crisis values. This event causes the ten companies in the sample to increase the value of their impairments due to traffic insolvencies, which are incorporated into their income statements, and consequently directly affects the economic results of the same. In turn, ratio R5, which measures the relative weight of the provision for bad debts of traffic operations with respect to the result of the fiscal year after taxes, reinforces the results obtained in the R1 ratio and reveals an increase of $107 \%$ for after the crisis. The companies double their value on provision in euros due to risk of client non-payment, which negatively affects the results as we advance the analysis of the R6 ratio that measures economic profitability. Nonetheless, the substantial change offered by the positive average results in the pre-crisis period and the negative average results in the post-crisis period cannot be justified entirely by the impact caused by the credit risk, as more variables, both internal and external, were caused by the crisis that could decisively influence these results. However, one of the many explanations is provided by this increase in the deterioration of commercial credit.

(b) All these negative events have occurred, although the companies in the sample have decreased the average term of collection of clients, represented in the $\mathrm{R} 4$ ratio, by $41 \%$ in the post-crisis period with respect to the pre-crisis period, which is equivalent to approximately 30 days. This assertion is reinforced by the fact that ratio R2, which measures the investment of commercial credit pending collection with respect to current assets, has decreased by $31 \%$ compared to the pre-crisis period. In turn, the R3 ratio, which measures the proportion of commercial credit with respect to total investments, current and noncurrent, has also decreased by $39 \%$. Although these indicators of low investment in commercial credit should provide better control of the risk of not being payed, this is not seen in reality.

The second objective was evaluated by considering the response to the relationships of the credit risk variable, synthetically created with the name "insolvency" for its statistical analysis and visualized through the provisions for insolvencies, the balance pending collection, the total of the investments, the result of the year and the net amount of the turnover. These variables were all reflected in the different economic-financial ratios and were ordered in relation to their ratings, as provided by a specialized and recognized worldwide evaluating companyin our case, Standard\& Poor's. This information was separately analysed in the two periods studied: thus, we conclude the following:

(a) Regarding the pre-crisis period (2002-2005), the synthetic variable "insolvency", which summarizes and agglutinates all the variables used in the formulation of the different ratios used in the statistical analysis related to credit risk and relation with the credit rating made by $\mathrm{S} \& \mathrm{P}$, shows a correlation of $32.9 \%$, where the three variables (ratios) R2, R3 and R4 are the most explanatory and, to a greater extent, reveal the variability of the data. The variable balance pending collection of customers appears in each of these three ratios and is compared with the investments and the economic results of the companies. 
(b) Regarding the post-crisis analysis (2012-2015), the data show a correlation between the variables of $38.2 \%$, which is slightly higher than the pre-crisis correlation. However, the same three variables (R2, R3 and R4) are maintained (the R4 ratio is explanatory) and have very similar values both in the pre and post-economic crisis period with 10 years of difference, as shown through factor analysis.

In short, it follows that the provision for insolvencies after the crisis and after ten years increases considerably. This increase negatively affects the results despite the companies' efforts to reduce the balance pending collection and to reduce average collection periods.

In turn, the economic results of their operating accounts are very affected after the crisis with respect to the precrisis period, but it is impossible to determine exactly the effect of the provision for insolvencies because there are more variables of which we are not aware.

The ratings of the companies in the sample have been adversely affected by the rating offered by rating agencies, in our case, Standard \& Poor's; in the pre-crisis period, the ratings oscillated on average from A to A-In the post-crisis period, the ratings oscillated on average between BBB and BBB-. The variables that incorporate the pending balance of collection, its investments and the results of the exercise are those that become more explanatory.

The rating companies, at present, focus more vigilance on the insolvency variable. In the past, for example, as seen in the cases of Enron and Lehman Brothers, such companies made errors in not anticipating or reflecting the real situations of the companies. Thus, they were criticized by governments for their slow reaction and accused of maintaining an oligopoly situation in the financial market; nevertheless, the governments have never been able to denounce the rating agencies because the agencies are registered as journalistic agencies and defend that they only express their opinions.

\section{Declaration of Conflicting Interests}

The authors declared no potential conflicts of interest with respect to the research, authorship, and/or publication of this article.

\section{Funding}

The authors received no financial support for the research, authorship, and/or publication of this article.

\section{References}

Abad, P., \& Robles, M.D (2014). ¿Reflejan los cambios de rating de la deuda variaciones en el riesgo de los emisores?. Revista Europea de Dirección y Economía de la Empresa, 24(2015), 47-60. https://doi.org/10.1016/i.redee.2014.04.001

Agnew, J.A. (2012). Baja geopolítica: Agencias de calificación crediticia, la privatización de la autoridad y la nueva soberanía. Geopolítica(s) ISSN: 2172-3958 2012, 3(2), 171-183. https://doi.org/10.5209/rev GEOP.2012.v3.n2.41349

Altman, E. (1968). Financial Ratios, Discriminant Analysis and the Prediction of Corporate Bankruptcy. The Journal of Finance, XIII(4), 589-609. https://doi.org/10.1111/i.1540-6261.1968.tb00843.x

Argüelles, R. (2007). Información más allá de las cuentas anuales: Del informe de gestión al Management Commentary. Partida Doble, 184, 46-61.

Beaver, W.H. (1966). Financial Ratios as Predictors of Failure. Empirical Research in Accounting: Selected Studies. Journal of Accounting Research, 5(supplement), 71-111. https://doi.org/10.2307/2490171

Brachfield, P.J. (2006). La lucha contra la morosidad. Las leyes europeas y españolas contra la morosidad descifradas y su aplicación práctica. Barcelona: Ediciones Gestión 2000.

Carmines, E.G., \& Zeller, R.A. (1979). Reliability and validity assessment (17). Beverly Hills, CA: Sage. https://doi.org/10.4135/9781412985642 
Cea García, J.L. (1992). In search of a better and more complete accounting information about the income risk. Comunicación presentada al XV Congreso de la EAA. Madrid.

Chuliá, C. (1991). El crédito Interempresarial. Una manifestación de la Desintermediación Financiera. Documento de Trabajo n ${ }^{\circ}$ 9221. Servicio de Estudios del Banco de España.

Chuliá, C. (1992). Desarrollo reciente del Crédito Interempresarial en España. Boletín Económico, Banco de España. Septiembre, pp.39-48.

Chuliá, C. (1993). La financiación Directa entre Familias y Empresas no Financieras: Evolución Reciente. Boletín Económico, Banco de España. Junio, pp.13-20.

Eijffinger, S.C.W. (2012). Rating Agencies: Role and Influence of Their Sovereign Credit Risk Assessment in the Eurozone. Journal of Common Market Studies, 50(6), 912-921. https://doi.org/10.1111/j.1468-5965.2012.02289.x

Emery, G. (1984). A Pure Financial Explanation for Trade Credit. Journal of Financial and Quantitative Analysis, 19(3), 271-285. https://doi.org/10.2307/2331090

Fernández del Pozo, L. (2001). Posibilidad y contenido de un derecho pre concursal. Auditoría y prevención de la crisis empresarial. Madrid-Barcelona.

Foster, G. (1986). Financial Statement Análisis (Second edition). USA: Prentixce Hall International Editions.

García Pérez de Lema, D., Calvo-Flores Segura, A., \& Arqués Pérez, A. (2000). Posición del riesgo financiero en la industria española. In Predicción de la Insolvencia Empresarial: Decisiones financieras y fracaso empresarial, monografia editada por la Asociación Española de Contabilidad y Administración de Empresas (AECA). Madrid: ISBN 84-89959-30-7.

García Vaquero, V., \& Maza, L. (1996). Crédito Interempresarial: Evolución reciente y efectos sobre el ciclo económico. Boletín Económico. Banco de España. Marzo, 29-45.

Garrido, L. (2000). El Riesgo en la gestión de cuentas de clientes. Estudios Financieros, 207,139-182.

Gonzalo Angulo, J.A. (2002) (Presidente). Informe sobre la situación actual de la contabilidad en España y líneas básicas para abordar su reforma (Libro Blanco para la reforma de la contabilidad en España). Madrid: ICAC.

Hernández de Cos, P., \& Hernando, L. (1999). El crédito comercial en las empresas manufactureras españolas. Moneda y Crédito, 209, 231-267.

Hilscher, J., \& Wilson, M. (2017). Credit Ratings and Credit Risk: Is One Measure Enough?. Management Science, 63(10), 3414-3437. https://doi.org/10.1287/mnsc.2016.2514

Instituto Nacional De Estadística (2007). Cuentas Económicas. Informe anual 2007.

Instituto Nacional De Estadística (2017). Cuentas Económicas. Informe anual 2017.

International Accounting Standars Board - IASB (2005). Discussion Paper Management Commentary.

Jiménez, G., \& Saurina, J. (2006). Ciclo crediticio, riesgo de crédito y regulación prudencial. Documento de trabajo núm. 0531 del Banco de España.

Jones, F.J. (1987). Current techniques in bankruptcy prediction. Journal of Accounting Literature, 6, 131-164.

Lev, B. (1978). Análisis de los estados financieros: Un nuevo enfoque. Madrid: ESIC.

Loiacono, E.T., Watson, R.T., \& Goodhue, D.L. (2002). WebQual: A measure of website quality. Marketing theory and applications, 13(3), 432-438.

Plataforma Multisectorial De Lucha Contra La Morosidad (2010). Nota de prensa de fecha 18 febrero.

Reglamento (CE) n 1060/2009 del Parlamento Europeo y del Consejo de 16 de Septiembre de 2009 sobre las agencias de calificación crediticia.

Reierson, R.L. (1959). The credit outlook. The journal of Finance, 14(2-May), 279-287.

https://doi.org/10.1111/j.1540-6261.1959.tb01587.x 
Samaniego, R., Trujillo, P., \& Martín, J.L. (2006). Un análisis de los modelos contables y de mercado en la evaluación del riesgo de crédito: Aplicación al mercado bursátil español. Revista Europea de Dirección y Economía de la Empresa, 16(2), 93-110.

Schwarts, R. (1974). An economic model of Trade Credit. Journal of Finance and Quantitative Analysis, Septiembre, 643-657. https://doi.org/10.2307/2329765

Stolpe, A. (2009). Regulation of credit rating agencies. Journal of Banking \& Finance, 33(7), 1266-1273. https://doi.org/10.1016/i.j.bankfin.2009.01.004

Suárez Suárez, A.S. (2003). Decisiones óptimas de inversión y financiación en la empresa (20 $\left.{ }^{\text {th }} \mathrm{ed}\right)$ (pp. 733-740). Madrid: Ediciones Pirámide.

Triple, A., \& Idea, A. (2009). Ending the rating oligopoly. Wall Street Journal, April 15th, 2009. Available at: http://online.wsj.com/article/SB123976320479019717.html

UNESPA - Asociación Empresarial del Seguro (2009). Memoria Social del Seguro Español. Madrid.

Vidal, R. (2001). La información sobre el riesgo empresarial: Una visión panorámica. Partida Doble, 121, 20-29.

Vicent Chuliá, F. (2002). Variaciones mercantiles sobre responsabilidad civil de los administradores y auditores, en vísperas de la unificación concursa., In RDP, 9, 2002.2, 85 \& ss.

Whittington, G. (1980). Some basic Properties of Accounting Ratios. Journal of Business Finance and Accounting, Estiu, 219-232. https://doi.org/10.1111/i.1468-5957.1980.tb00738.x

Zavgren, C. (1983). The prediction of corporate failure: the state of art. Journal of Accounting Literature, 2, 1-38.

Intangible Capital, 2020 (www.intangiblecapital.org)

Article's contents are provided on an Attribution-Non Commercial 4.0 Creative commons International License. Readers are allowed to copy, distribute and communicate article's contents, provided the author's and Intangible Capital's names are included. It must not be used for commercial purposes. To see the complete license contents, please visit https://creativecommons.org/licenses/by-nc/4.0/. 